\title{
Medicinal plants of the Unified Health System (Sistema Único de Saúde) with antifungal potential
}

Plantas medicinais do Sistema Único de Saúde com potencial antifúngico

Mônica Jachetti Maciel ${ }^{1}$ (D), Claudete Rempel ${ }^{1}$ (), Amanda Luisa Stroher ${ }^{1}$ (D), Patrícia Caye Bergmann ${ }^{1}$ (D), Diorge Jônatas Marmitt ${ }^{1}$ (1)

\begin{abstract}
A B S T RAC T
Medicinal plants synthesize various secondary metabolites that can be used for therapeutic and antimicrobial purposes. In Brazil, the Unified Health System (SUS) offers several herbal medicines as an alternative in the treatment of various diseases. Considering the importance of these plants in the production of chemicals that expand therapeutic options and improve the health of SUS users, this review was carried out to quantitatively determine the antifungal activity of plants used as phytotherapeutics at RENAME. The selection of papers was performed at three distinct stages: examining and choosing titles related to antifungal action, reading the abstracts, and reading the whole selected articles. This review selected 22 studies of interest; 12 of them were conducted in Brazil and 10 were carried out in other countries. The papers chosen tested the growth inhibitory effect of plants against fungal species of agricultural and health importance, ranging from filamentous to yeast-like fungi, and Candida albicans was the most tested species. The growth of 39 fungal species were inhibited by some concentration of the extract used, with either an increase or decrease in antifungal activity depending on the extract used. The most frequently analyzed plant was the species Schinus terebinthifolius Raddi., studied in seven papers. The results found demonstrate the importance of analyzing medicinal plants and incorporating plant-based medicines in healthcare as an alternative source of treatment, highlighting the need for studies that evaluate the mechanisms action of their cytotoxicity and therapeutic effects in the human body.
\end{abstract}

Keywords: herbal medicines; fungi; secondary metabolites.

\section{R E S U M 0}

As plantas medicinais produzem uma série de metabólitos secundários que podem ser usados para fins terapêuticos e antimicrobianos. No Brasil, o SUS disponibiliza uma série de medicamentos fitoterápicos como alternativa ao tratamento de diversas enfermidades. Considerando a importância da utilização dessas plantas na produção de medicamentos que ampliem as opções terapêuticas e melhorem a atenção à saúde de usuários do sistema, elaborou-se este estudo de revisão com o objetivo de estimar quantitativamente a atividade antifúngica das plantas utilizadas como fitoterápicos contidas na RENAME. A seleção de artigos deu-se por meio de três etapas distintas: leitura e escolha de títulos relacionados à ação antifúngica, leitura dos resumos e leitura na íntegra dos artigos selecionados. Esta revisão selecionou 22 estudos de interesse, sendo 12 elaborados no Brasil e 10 em outros países. Os artigos escolhidos testaram a ação inibitória das plantas contra espécies de fungos de importância agrícola e sanitária, entre filamentosos e leveduriformes, sendo Candida albicans a espécie mais testada. Trinta e nove espécies foram inibidas por alguma concentração do extrato utilizado, havendo aumento ou diminuição da atividade antifúngica conforme substância extratora utilizada. A planta mais analisada foi a espécie Schinus terebinthifolius Raddi., estudada em sete artigos. Os resultados encontrados demonstram a importância da análise de plantas medicinais e da incorporação de medicamentos à base de plantas como fonte alternativa de tratamento, salientando a necessidade de estudos que demonstrem sua citotoxicidade e mecanismos de ação terapêutica no organismo humano.

Palavras-chave: medicamentos fitoterápicos; fungos; metabólitos secundários. \footnotetext{
E-mail: monicajm@univates.br do Sul (FAPERGS).

Received on: 04/22/2020. Accepted on: 08/31/2020

https://doi.org/10.5327/Z21769478766
}

${ }^{1}$ Universidade do Vale do Taquari (Univates) - Lajeado (RS), Brazil.

Correspondence address: Mônica Jachetti Maciel - Avenida Avelino Talini, 171 - Bairro Universitário - CEP: $95914-014$ - Lajeado (RS), Brazil.

Conflicts of interest: the authors declare that there are no conflicts of interest.

Funding: Conselho Nacional de Desenvolvimento Científico e Tecnológico (CNPq) and Fundação de Amparo à Pesquisa do Estado do Rio Grande

This is an open access article distributed under the terms of the Creative Commons license. 


\section{Introduction}

the set of chemical reactions performed by plants produces a series of substances called secondary metabolites, which include flavonoids, tannins, alkaloids, saponins, coumarins and quinones, also encompassing the so-called essential oils or essences. These metabolites have various functions, which are related to the defense against animals, insects and other plants, protection from physical factors and attraction of animals for reproductive purposes (Simões et al., 2017; Tamariz-Angeles et al., 2018). In addition, many of these substances are important for characterizing and confirming the identity and quality of the plant in question, also manifesting antimicrobial activities, especially against bacteria, protozoa and fungi (Maciel et al., 2017).

Several studies have shown the beneficial use of extracts and active principles extracted from plants against pathogens that can infect and cause harm to animals, humans and plant crops (Chansue, 2007; Itako et al., 2009; Marmitt et al., 2015a; 2015b; Pinho et al., 2012; Rodrigues et al., 2007). New antimicrobial assets derived from natural sources can decrease the amount of pesticides and other chemical products for environmental control applied on farms, reducing the risks to our health and to the environment. Hence, they become a safer - and often more effective - alternative than pesticides (Mauli et al., 2009; Schwan-Estrada et al., 2000). they can also be an alternative to prevent many microorganisms from developing resistance to drugs used for their control, which increases the incidence of diseases caused by these pathogens and hampers the treatment of people affected (Cavalcanti et al., 2012; França et al., 2009; Maciel et al., 2017; Nogueira et al., 2008).

In 2009, the National List of Medicinal Plants of Interest to SUS (RENISUS) was established. Consisting of 71 plant species with therapeutic potential according to traditional medicine knowledge, with the purpose of promoting the study of herbal medicines and their production in Brazil (Brazil, 2009a; 2009b). The provision of plant-derived medicines by the Brazilian public healthcare system began in 2007 through the National List of Essential Medicines (RENAME) (Brazil, 2017b), and currently comprises 12 plants: Aloe vera (L.) Burm.f., Cynara scolymus L., Glycine max (L.) Merr., Harpagophytum procumbens (Burch.) DC. ex Meisn., Maytenus ilicifolia Mart. ex Reissek, Mentha piperita L., Mikania glomerata Spreng., Plantago ovata Forssk, Rhamnus purshiana DC., Salix alba L., Schinus terebinthifolius Raddi, and Uncaria tomentosa (Willd. ex Schult.) DC.; offered in the form of syrups, tablets, capsules, gels, creams and dyes (Brazil, 2012; 2017a; 2017b).

Considering the purpose for which RENISUS has been created, the aim of this systematic review was to show the amount of studies published on medicinal plants with antifungal activity as described in the national list of medicinal plants provided by SUS, using the CAPES (Coordination for the Improvement of Higher Education Personnel) Journals Portal as database, which encompasses publications from several other platforms, such as SciELo, PubMed and Springer, among others.

\section{Materials and methods}

The present study used a systematic review of the literature as a technical procedure for gathering scientific information encompassing different cases, locations and perspectives from different researchers, summarizing their objectives and results in a simplified manner (Greenhalgh, 1997; Carneiro; Takayanagui, 2009). The studies addressed here were those concerning the antifungal potential of medicinal plants provided as phytotherapeutics by SUS through RENISUS, and those with the full text available at the Capes Journals Portal in English, Portuguese or Spanish, were analyzed with no restrictions as to their publication year. Descriptors used were the scientific names of the plants (or phytotherapeutics) at RENAME and the term "antimicrobial", followed by the Boolean operator "and", with no restrictions of language or publication year.

The access link used was the one made available in the database. The titles of all the papers found when searching each species were read and the repeated ones were excluded, thus being counted only once. Review studies, interviews, reports, and studies on the practical use of plants or referring to their chemical constituents without either confirming or proving their antifungal effect were also excluded.

A total of 10,763 articles were found in the initial search; 382 were reports and 267 were repeated scientific papers, and they were thus excluded from the study. Of all articles found in the initial search, 417 studies were selected to comprise the further stages of this review. The publications chosen were analyzed in three stages: first, by reading the title of all articles found in the database, and selecting those that included terms related to antifungals, such as "fungos", "fungi", "levedura", "yeast”, “Aspergillus", “Candida”, "Penicillium”, “Fusarium” and "antifúngico", among others. A total of 67 studies were selected. Afterwards, the next stage consisted of reading the abstracts of the papers selected in the first stage, which resulted in 32 papers selected. Those that somehow mentioned the method used and proved the antifungal effect of the studied plant were chosen. In the third and last stage, the papers selected in the second phase were completely read, to prove the antifungal effect of the plants of interest, and 22 studies were found to be compatible with the criteria established here, and were thus chosen to be included in the present review. The scientific names of the plants mentioned were written according to updated references for native plants in Brazil (Reflora, 2010) and introduced plants (Taxonomic Name Resolution Service, 2020).

During the search, a methodological adjustment was required to include the plant Glycine max. While using the same procedure adopted for the other plants, it was not possible to read the papers available starting on page 281 due to problems in the platform used for the search. To complete the search for this plant, restricting the publication year to 2009, the year in which RENISUS was created, was required. Only with this adjustment, was it possible to access all the studies published as of this date and the search for this descriptor was not complete. 


\section{Results and Discussion}

After reading the 32 selected papers completely, 22 studies of interest were selected for inclusion in the present review, which corresponds to $5.3 \%$ of the total relevant papers initially found in the database. Chart 1 shows the total number of papers selected for each study of interest of each plant analyzed, followed by methodology and main results.

Of the 12 plants that comprised this study, no studies on Maytenus ilicifolia, Salix alba and Rhamnus purshiana were selected, due to the fact that none of the papers found met the selection criteria. The papers were organized in a distribution chart by antifungal potential and therapeutic action (Chart 1). There were three publications in 2011, which was the year with the highest number of publications. The most recent research among the papers selected was from 2017, and the oldest was from 2002.

Of the 22 selected studies, 12 (54.5\% of the total) were conducted by Brazilian researchers (Biasi-Garbin et al., 2016; Braga et al., 2007; Duarte et al., 2005; Freire et al., 2012; Holetz et al., 2002; Johann et al., 2008; Martinelli et al., 2017; Moraes et al., 2015; Moura-Costa et al., 2012; Schmourlo et al., 2005; Santos et al., 2010; Souza Júnior et al., 2011), which indicates that the creation of RENISUS did promote medicinal plant studies in Brazil.

Reports indicate that medicinal plants were already used in Europe in 460 B.C. in the form of hot and iced teas, moist compresses and dried herbs. They are still used today by many European countries as complementary medicines in the treatment of many diseases. Several other cultures have also relied on the properties of medicinal plants for thousands of years, with several species still in use to date (Van Wyk; Wink, 2018). Of the 22 selected articles in this study, nine (41\%) were carried out in other countries, especially India and Iran, with two studies each. The most tested plants in these studies were Mentha piperita, with 6 studies, and Cynara scolymus, with 2 studies.

In the international scenario, studies on medicinal plants, especially those focused on public health systems, have been disseminated since the First International Conference on Primary Health Care, held in 1978 in Russia (Gonçalves et al., 2017). Heinrich (2010), studying medicinal plants worldwide, indicated an increase in the search for phytotherapeutics for the treatment of AIDS/HIV and viral diseases. In the same study, he points out that research has focused on the innovation of phytochemical studies for the isolation and identification of active ingredients. Since 1979, the World Health Organization has suggested the inclusion of complementary alternative medicine therapies in public health policies, with their use reaching $75 \%$ in France, $70 \%$ in Canada, and $42 \%$ in the USA (Zeni et al., 2017).

Estimates indicate that $70-80 \%$ of drug development depends exclusively on plants, and much of the research in this area is focused on the isolation of plant active ingredients (Aslam; Ahmad, 2016). According to Rajeswara Rao and Rajput (2010), the major research areas on medicinal plants in the world are: development of technologies for the cultivation and isolation of chemical compounds, im- plementation of quality control protocols, scientific validation of the traditional use of these plants, development of products using them as a production base, selection of markers for genotypes, creation of a DNA profile of the species studied, identification and isolation of enzymes and bioactive molecules, and screening of phytochemical compounds with antimicrobial properties.

The nine international studies selected for this review were in vitro and $66.7 \%$ (6) also analyzed the chemical compounds present in the study plant, using chromatographic methods. None of them, however, identified the specific compound accounting for the antifungal activity observed.

Of the international studies selected, seven $(77.8 \%)$ were carried out after 2010, one of which was published in 2019. Compared to the Brazilian studies, where $58.3 \%$ were published in or after 2010, there was an increase in studies in this area at the global level after this period. In a comparative study, Assis et al. (2015) showed a strong growth trend in research on medicinal plants in analyzing 111 research groups between 1997 and 2010, a trend that has continued to intensify in later years.

It is known that most medicinal plants are available in tropical countries (Dar et al., 2017). India and Iran stood out as the countries with the highest number of papers of interest, with two studies each (Desam et al., 2019; Tyagi; Malik, 2011; Saharkhiz et al., 2012; Mahboubi; Kazempour, 2014), having an important diversity of plants relevant to the healthcare area (Panda et al., 2018; Tandon; Yadav, 2017; Sadat-Hosseini et al., 2017; Parsaei et al., 2016).

The pharmacology of natural products allows determination of the bioactive compounds present in plants, that are responsible for growth-inhibitory effects. These bioactive compounds, also called secondary metabolites, have antimicrobial effects due to their cytotoxicity, and because of their neuroactive effects, they can be used as analgesics, anesthetics and antidepressants, among others (Vizzotto et al., 2010). As indicated by Piriz et al. (2014), medicinal plants have several beneficial properties that can be used for the benefit of humans. In their study, Piriz et al. (2014) found relevant results of studies on anti-inflammatory activity, especially in Brazil, which was the country with the highest number of papers published. The same number of papers produced in Brazil (12) was found in the present study, showing the importance and competence of Brazilian research demonstrated in this area.

Marmitt et al. (2015b), in a review, searched for plants with antibacterial effect in RENISUS, and found that $42 \%$ of the 19 selected published studies of interest were conducted in Brazil, thus indicating an increase in studies in the country after the creation of the National Policy on Medicinal and Herbal Plants (PNPMF). Similar results were found in the present study: of the 13 studies carried out in Brazil, 69\% (9) were published after the creation of PNPMF. PNPMF (Brazil, 2006) has contributed to the increase in research aimed at the development of new plant-derived drugs, which are already used popularly in conventional medicine. 
Chart 1 - Antifungal potential and therapeutic action of medicinal plants evaluated in the studies of interest selected.

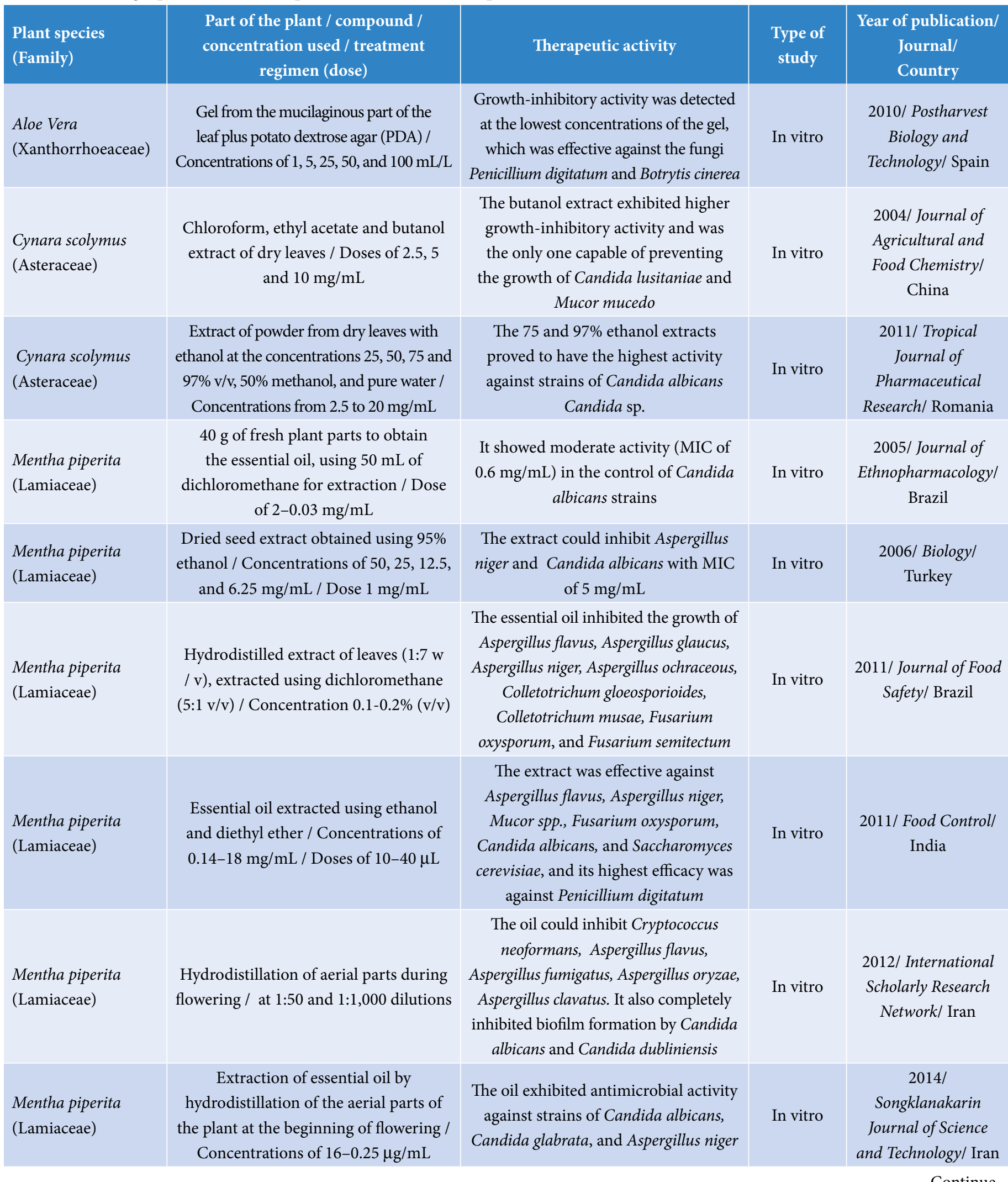


Chart 1 - Continuation.

\begin{tabular}{l|c} 
Plant species & $\begin{array}{c}\text { Part of the plant / compound / } \\
\text { concentration used / treatment } \\
\text { (Family) }\end{array}$ \\
regimen (dose)
\end{tabular}

Hydrodistillation of dry leaves to obtain

Mentha piperita

(Lamiaceae)

the extract dissolved in $95 \%$ ethanol

/ Concentrations of 4, 2, 1, 0.5, 0.25, $0.125 \mu \mathrm{L} / \mathrm{mL}$

\begin{tabular}{l|l}
$\begin{array}{l}\text { Mentha piperita } \\
\text { (Lamiaceae) }\end{array}$ & Hydrodistillation at $1: 5$ concentration / \\
dose of $1 \mu \mathrm{L}$
\end{tabular}

Mikania glomerata

(Asteraceae)

Mikania glomerata
(Asteraceae)

\section{Schinus}

terebinthifolius

(Anacardiaceae)

\begin{tabular}{l|c} 
Schinus & Methanol extract $(3: 2,000) /$ Dose of \\
terebinthifolius & $100 \mathrm{mg} / \mathrm{mL}$ \\
(Anacardiaceae) &
\end{tabular}

Oil extraction from leaves with

\section{Schinus}

terebinthifolius

(Anacardiaceae) $80 \%$ ethanol and addition of water, hexane, dichloromethane and ethyl acetate / Concentrations from 1,000 to $7.8 \mu \mathrm{g} / \mathrm{mL}$

\begin{tabular}{|c|c|}
\hline $\begin{array}{l}\text { Schinus } \\
\text { terebinthifolius } \\
\text { (Anacardiaceae) }\end{array}$ & $\begin{array}{c}\text { Extract obtained by hydrodistillation / } \\
\text { Concentrations of } 25,50,75 \text { and } 100 \% \text { / } \\
\text { Dose of } 100 \mu \mathrm{L} / \mathrm{mL}\end{array}$ \\
\hline
\end{tabular}

\section{Schinus}

terebinthifolius

(Anacardiaceae)

\section{Schinus}

terebinthifolius

(Anacardiaceae)

Lower parts of the plant were macerated with water and ethanol (90-10\%) /

$$
\text { Dose of } 2 \mathrm{mg} / \mathrm{mL}
$$

$40 \mathrm{~g}$ of fresh parts of the plant were used to obtain the essential oil, using 50 $\mathrm{mL}$ of dichloromethane for extraction / Dose of $2-0.03 \mathrm{mg} / \mathrm{mL}$

Aqueous-ethanol extract (20:3 mg/mL) from the aerial parts / Concentration of $1 \mathrm{mg} / \mathrm{mL}$

$$
\text { (1:10) / Dose of } 2 \mathrm{mg} / \mathrm{mL}
$$

Aqueous, ethanol and acetone extracts

/ Concentrations from 1,000 to $1.95 \mu \mathrm{g}$ / $\mathrm{mL} /$ Dose of $2,000 \mu \mathrm{g} / \mathrm{mL}$
The aqueous extract was able to prevent the growth of Candida albicans It exhibited antifungal activity against Candida albicans and Cryptococcus neoformans

It prevented the growth of Microsporum canis, Epidermophyton floccosum, Trichophyton rubrum, and Trichophyton mentagrophytes at concentrations of 2.0 and $4.0 \mu \mathrm{L} / \mathrm{mL}$

The essential oil exhibited strong antifungal activity against Alternaria, Penicillium spp., Fusarium oxysporum, Fusarium tabacinum, Aspergillus fumigatus, Candida albicans, Cladosporium herbarum, and Rhizoctonia solani

It exhibited moderate activity (MIC of $100-500 \mu \mathrm{g} / \mathrm{mL}$ ) against Candida krusei and Candida parapsilosis

It exhibited weak inhibitory activity (MIC $>2.0 \mathrm{mg} / \mathrm{mL}$ ) compared to Candida albicans

Type of
study Year of publication/ Journal/ Country

2015/ Environmental Health and

In vitro

Preventive Medicinel Egypt

2017/ Journal of King In vitro Saud University/ India

2002/ Memórias do In vitro Instituto Oswaldo Cruz/ Brazil

2005/ Journal of In vitro Ethnopharmacology/ Brazil 2005/ Journal of In vitro Ethnopharmacology/ Brazil 2007/ Journal of In vitro Ethnopharmacology/ Brazil

The ethyl acetate extract portion exhibited higher antifungal activity against strains of Candida albicans

In vitro 2008/ World Journal of Microbiology and Biotechnology/ Brazil

The $25 \%$ dilution was able to inhibit the growth of Colletotrichum sp., Alternaria spp. and Botrytis spp.

Fusarium spp. was only inhibited by the $50 \%$ dilution

It exhibited inhibitory activity against strains of Candida tropicalis and

$$
\text { Candida parapsilosis }
$$

Ethanol extract exhibited strong activity against Trichophyton rubrum and Trichophyton mentagrophytes

\section{0/Revista}

Brasileira de

In vitro

Farmacognosial

Brazil

2012/ Journal of

In vitro Ethnopharmacology/

Brazil

2016/Revista do

Instituto de Medicina

Tropical de São

Paulo/ Brazil 


\section{Chart 1 - Continuation.}

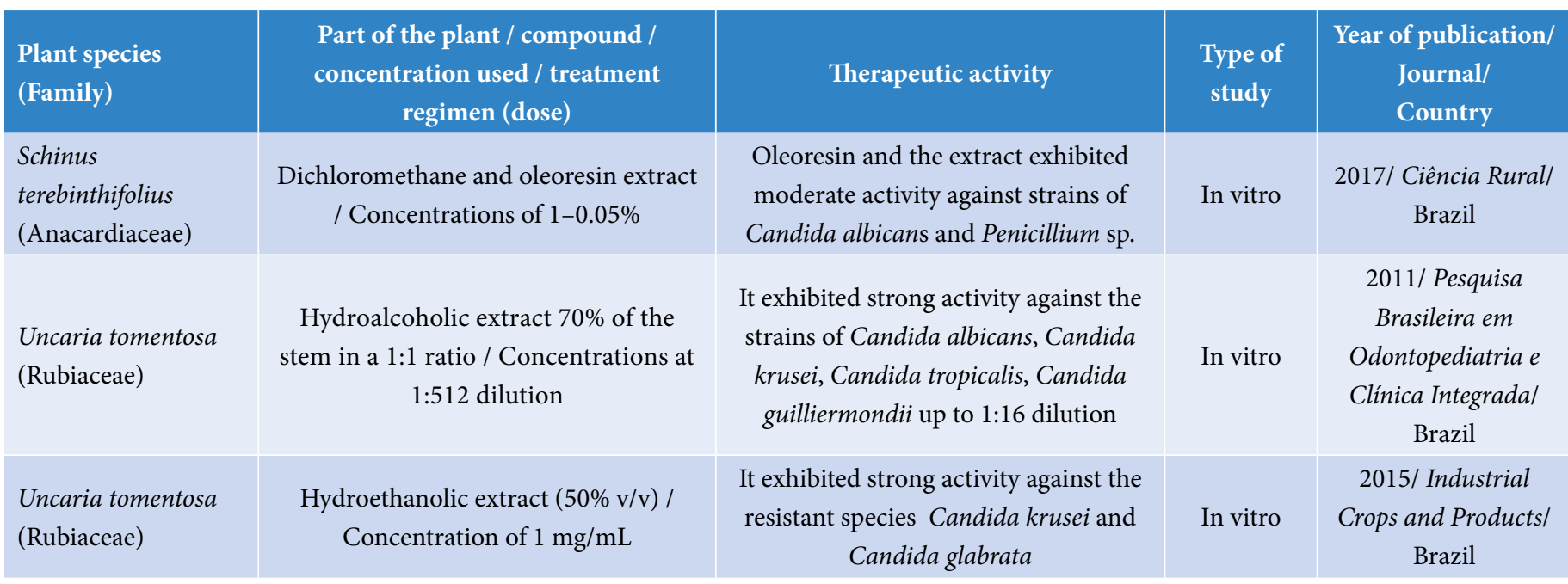

Source: Castillo et al. (2010), Ertürk (2006), Ibrahim and El-Salam (2015), Vamanu et al. (2011) and Zhu et al. (2004).

Different numbers of papers were found for each plant species selected, indicating a variety and effectiveness of different mechanisms of action in each species. The therapeutic activity shown is related to the extraction method and dose used. Extraction using aqueous-ethanol solvents afforded higher growth-inhibitory activity (27 different strains growth-inhibited), followed by extraction of essential oils using hydrodistillation (22 different strains growth-inhibited) and extraction using dichloromethane (12 different strains growth-inhibited). Different solvents extract different active principles from the plant, which are responsible for the effects caused by the use of medicines containing these substances (e.g., anti-inflammatory, hypoglycemic, anticoagulant and antiplatelet activities) (Sixel; Pecinalli, 2005).

Studies show that the use of the crude extract, shows a considerably higher bioactivity than using each active principle separately (Sixel; Pecinalli, 2005). The studies analyzed in this review, therefore, showed higher antimicrobial activity, since all the assays were performed using crude extracts. Among all the plants analyzed, approximately 54\% (12) showed growth-inhibition in all of the fungal species tested, and $41 \%$ (9) at least prevented the growth of $50 \%$ of the species analyzed. The butanol extract of Schinus terebinthifolius was tested against Candida neoformans, Candida albicans, and Trychophyton rubrum, and inhibited only Candida albicans strains.

Analyzing the data obtained, Candida albicans was the most tested microorganism in all papers selected, totaling 16 studies analyzing extracts and oils against strains of this species. Overall, 18 studies $(78.3 \%$ of the total) analyzed seven Candida species regarding their sensitivity to medicinal plant extracts and oils. Filamentous fungi were also part of the selected studies. Nine species of Aspergillus were used in seven articles (39.2\% of the total), and Aspergillus niger was most studied, appearing in six papers.
According to Correia et al. (2006), the family Anacardiaceae is rich in bioactive compounds that may have antimicrobial effects, with the genus Schinus being among the 11 most studied in this family. Correia et al. (2006) demonstrated the presence of phenolic lipids in this plant. These compounds have amphipathic characteristics, which facilitate their penetration into the plasma membrane, causing changes in their structure and properties. Therefore, seven of the 22 studies selected for this review analyzed the bioactive and antimicrobial activity of Schinus terebinthifolius, which prevented the growth of $78 \%$ (14) of the 18 strains tested.

Another important factor, pointed out by Gobbo-Neto and Lopes (2007), indicates that changes in the concentrations of active compounds may occur due to circadian cycle (day/night), seasonality, plant age, development period, temperature, attack by pathogens, pollution, and the hormonal development process in the plant. Evans (2009) showed significant differences in the presence of chemical compounds during winter and summer. Vasconcelos Silva et al. (1999) demonstrated how the circadian cycle affects the production and concentration of bioactive substances, showing high quantitative contrasts at different times of the day.

Stress caused by temperature variations can also affect the concentrations of these compounds, as indicated by Christie et al. (1994). Plant age is also related to these changes. Flowering period leads to increase or decrease in certain substances, as well as the period of leaf emergence or loss in deciduous plants. This indicates why the same plant species had different results in this paper. Two studies carried out with Mentha piperita (Mahboubi; Kazempour, 2014) (Saharkhiz et al., 2012) used Aspergillus flavus samples to test the antimicrobial action of essential oils extracted using hydrodistillation. The first study used the 
aerial parts at the beginning of flowering to obtain essential oils and observed excellent growth-inhibitory activity. However, the second study, which also used aerial parts to extract essential oils, although after the beginning of flowering, found no growth-inhibitory action at any concentration in Aspergillus flavus strains.

The same occurred in studies carried out by Schmourlo et al. (2005) and Biasi-Garbin et al. (2016), who tested the action of the ethanol extract of the species Schinus terebinthifolius. The extract was prepared using different parts of the plant in each study, differing only in the concentration used (Chart 1). At the end of the study, Biasi-Garbin et al. (2016) were able to inhibit the growth of the pathogenic fungus Trichophyton rubrum, while Schmourlo et al. (2005) showed no effect on this fungus. Schmourlo et al. (2005) and Braga et al. (2007) conducted a study with the same plant species using extracts against Candida neoformans strains. Alcoholic extracts were obtained for both studies; Schmourlo et al. (2005) used ethanol as extraction solvent and Braga et al. (2007) used methanol. In the first study, the extract did not prevent the growth of Candida neoformans, while it was inhibited in the second study, thus indicating that different solvents affect the composition of bioactive substances, either intensifying or preventing the effect of the extract, as already observed by Silva (2010). Silva (2010) compared different extracts of essential oils, classifying the different activities exhibited by each extract.
Thus, he identified significant differences in the action of different solvents, related to solubility and affinity with the plasma membrane of the strains he compared.

\section{Conclusion}

Of the 417 papers initially read, 22 that demonstrated an antifungal effect were selected for the present review. The two plants that exhibited the highest antifungal activity were Mentha piperita, with eight studies, and Schinus terebinthifolius, with seven studies. Candida albicans was the most frequently tested fungal species, as it was present in 11 different studies. Other species of the genus Candida were tested in 10 different studies. The genera Fusarium and Aspergillus also stood out, with five and 13 studies, respectively.

The incorporation of integrative and complementary practices within the scope of SUS through PNPMF helps to understand and perceive the importance of studies on this topic. RENAME has also played an important role in the increase and constant evolution of the research on herbal medicines in Brazil, especially after their inclusion in SUS.

There is a therapeutic equivalence between essential oils and extracts used to obtain active ingredients. Thus, the importance of evaluating these compounds for cytotoxicity, bioavailability and therapeutic action in humans is evident to ensure that they can be used as drugs, having proven their extensive activity against microorganisms.

\section{Contribution of authors:}

Maciel, M. J.: Supervision, Funding Acquisition, Formal Analysis, Writing, Review \& Editing. Rempel, C.: Supervision, Funding Acquisition, Formal Analysis, Writing, Review \& Editing. Stroher, A. L.: Methodology, Investigation, Data Curation, Writing. Bergmann, P. C.: Methodology; Investigation, Data Curation, Writing. Marmitt, D. J.: Supervision, Formal Analysis, Writing, Review \& Editing.

\section{References}

Aslam, M.S.; Ahmad, M.S., 2016. Worldwide importance of Medicinal Plants: Current and Historical Perspectives. Recent Advances in Biology and Medicine, v. 2, 88 - 93.

Assis, M.A.; Morelli-Amaral, V.F.; Pimenta, F.P., 2015. Research groups and their scientific literature on medicinal plants: an exploratory study in the state of Rio de Janeiro. Revista Fitos, v. 9, (1), 45 - 54. http://doi.org/10.5935/24464775.20150005

Biasi-Garbin, R.P.; Demitto, F.O.; Amaral, R.C.R.; Ferreira, M.R.A.; Soares, L.A.L.; Svidzinski, T.I.E.; Baeza, L.C.; Yamada-Ogatta, S.F., 2016. Antifungal potential of plant species from Brazilian caatinga against dermatophytes. Revista do Instituto de Medicina Tropical, v. 58, (18). https://doi.org/10.1590/ S1678-9946201658018

Braga, F.G.; Bouzada, M.L.M.; Fabri, R.L.; Matos, M.O.; Moreira, F.O.; Scio, E.; Coimbra, E.S., 2007. Antileishmanial and antifungal activity of plants used in traditional medicine in Brazil. Journal of Ethnopharmacology, v. 111, (2), 396 402. https://doi.org/10.1016/j.jep.2006.12.006
Brazil, 2006. Ministério da Saúde. Política Nacional de Plantas Medicinais e Fitoterápicos. Brasil, Ministério da Saúde (Accessed December 28, 2018), at: http://bvsms.saude.gov.br/bvs/publicacoes/politica_nacional_ fitoterapicos.pdf.

Brazil, 2009a. Ministério da Saúde. MS elabora Relação de Plantas Medicinais de Interesse ao SUS. Brasília, Ministério da Saúde (Accessed December 28, 2018), at: http://bvsms.saude.gov.br/bvs/sus/pdf/marco/ms_relacao_plantas_ medicinais_sus_0603.pdf

Brazil, 2009b. Ministério da Saúde. Secretaria de Ciência, Tecnologia e Insumos Estratégicos. Departamento de Assistência Farmacêutica e Insumos Estratégicos. Programa Nacional de Plantas Medicinais e Fitoterápicos. Brasília, Ministério da Saúde. (C. Projetos, Programas e Relatórios.)

Brazil, 2012. Ministério da Saúde. Portal da Saúde. Portaria n. 533, de 28 de março de 2012. Estabelece o elenco de medicamentos e insumos da Relação Nacional de Medicamentos Essenciais (RENAME) no âmbito do Sistema Único de Saúde (SUS). Diário Oficial da União, Brasília. 
Brazil, 2017a. Ministério da Saúde. Secretaria de Ciência, Tecnologia e Insumos Estratégicos. Departamento de Assistência Farmacêutica e Insumos Estratégicos. Relação Nacional de Medicamentos Essenciais: RENAME 2017. Brasília, Ministério da Saúde.

Brazil, 2017b. Ministério da Saúde. Relação de fitoterápicos oferecidos pelo SUS. Brasília, Ministério da Saúde (Accessed December 26, 2018), at: http:// www.brasil.gov.br/noticias/saude/2012/11/sus-tem-fitoterapicos-paradoencas-simples/relacao-de-fitoterapicos-oferecidos-pelo-sus/view.

Carneiro, R.M.A.; Takayanagui, A.M.M., 2009. Estudos sobre bioindicadores vegetais e poluição atmosférica por meio de revisão sistemática da literatura. Revista Brasileira de Ciências Ambientais (Online), (13), 26 - 44.

Castillo, S.; Navarro, D.; Zapata, P.J.; Guillén, F.; Valero, D.; Serrano, M.; Martínez-Romero, D., 2010. Antifungal efficacy of Aloe vera in vitro and its use as a preharvest treatment to maintain postharvest table grape quality. Postharvest Biology and Technology, v. 57, (3), 183 - 188. https://doi. org/10.1016/j.postharvbio.2010.04.006

Cavalcanti, Y.W.; Pérez, A.L.A.L.; Xavier, G.D.R.; Almeida, L.F.D.A.; Padilha, W.W.N., 2012. Atividade Antifúngica de Extratos Vegetais Brasileiros sobre Cepas de Candida. Revista Brasileira de Ciências da Saúde, v. 16, (1), 43 - 48. https://doi.org/10.4034/RBCS.2012.16.01.07

Chansue, N., 2007. Effects of dried Indian almond leaf (Terminalia catappa L.) extract on monogenean parasites in goldfish (Carassius auratus). Wiener Tierarztliche Monatsschrift, v. 94, (11-12), 269 - 273.

Christie, P.J;; Alfenito, M.R.; Walbot, V., 1994. Impact of low-temperature stress on general phenylpropanoid and anthocyanin pathways: Enhancement of transcript abundance and anthocyanin pigmentation in maize seedlings. Planta, v. 194, (4), 541 - 549. https://doi.org/10.1007/BF00714468

Correia, S.J.; David, J.P.; David, J.M., 2006. Metabólitos secundários de espécies Anacardiaceae. Química Nova, v. 29, (6), 1287 - 1300. https://doi.org/10.1590/ S0100-40422006000600026

Dar, R.A.; Shahnawaz, M.; Qazi, P.H., 2017. General overview of medicinal plants: A review. Journal of Phytopharmacology, v. 6, (6), 349 - 351

Desam, N.D.R.; Al-Rajab, A.J.; Sharma, M.; Mylabathula, M.M.; Gowkanapalli, R.R.; Albratty, M., 2019. Chemical constituents, in vitro antibacterial and antifungal activity of Mentha $\times$ Piperita L.(peppermint) essential oils. Journal of King Saud University-Science, v. 31, (4), 528 - 533. https://doi.org/10.1016/j.jksus.2017.07.013

Duarte, M.C.T.; Figueira, G.M.; Sartoratto, A.; Rehder, V.L.G.; Delarmelina, C., 2005. Anti-Candida activity of Brazilian medicinal plants. Journal of Ethnopharmacology, v. 97, (2), 305 - 311. https://doi.org/10.1016/j.jep.2004.11.016

Ertürk, O., 2006. Antibacterial and antifungal activity of ethanolic extracts from eleven spice plants. Biologia, v. 61, (3), 275 - 278. https://doi.org/10.2478/ s11756-006-0050-8

Evans, W.C., 2009. Trease and Evans Pharmacognosy. International Edition E-Book. Elsevier Health Sciences, Philadelphia.

França, H.S.; Kuster, R.M.; Rito, P.N.; Oliveira, A.P.; Teixeira, L.A.; Rocha, L., 2009. Atividade antibacteriana de floroglucinóis e do extrato hexânico de Hypericum brasiliense Choysi. Química Nova, v. 32, (5), 1103 - 1106. https:// doi.org/10.1590/S0100-40422009000500004

Freire, M.M.; Jham, G.N.; Dhingra, O.D.; Jardim, C.M.; Barcelos, R.C.; Valente, V.M.M., 2012. Composition, antifungal activity and main fungitoxic components of the essential oil of Mentha piperita L. Journal of Food Safety, v. 32, (1), 29 - 36. https://doi.org/10.1111/j.1745-4565.2011.00341.x

Gobbo-Neto, L.; Lopes, N.P., 2007. Plantas medicinais: fatores de influências no conteúdo de metabólitos secundários. Química Nova, v. 30, (2), 374 - 381. https://doi.org/10.1590/S0100-40422007000200026
Gonçalves, A.L.S.; Cruz, A.P.N.; Silva, M.L.F.; Oliveira, M.D., 2017. Uso da fitoterapia na atenção básica: uma revisão de literatura. In: Congresso Nacional de PICS, 1.; Encontro Nordestino de PICS, 3., 2017. Annals...

Greenhalgh, T., 1997. How to read a paper: Papers that summarise other papers (systematic reviews and meta-analyses). Education and Debate, v. 315, 672 - 675. https://doi.org/10.1136/bmj.315.7109.672

Heinrich, M., 2010. Ethnopharmacology in the 21 century-grand challenges. Frontiers in Pharmacology, v. 1, (8), 1 - 3. https://doi.org/10.3389/ fphar.2010.00008

Holetz, F.B.; Pessini, G.L.; Sanches, N.R.; Cortez, D.A.G.; Nakamura, C.V.; Dias Filho, B.P., 2002. Screening of Some Plants Used in the Brazilian Folk Medicine for the Treatment of Infectious Diseases. Memórias do Instituto Oswaldo Cruz, v. 97, (7), 1027 - 1031. https://doi.org/10.1590/S0074-02762002000700017

Ibrahim, S.Y.; El-Salam, M.M.A., 2015. Anti-dermatophyte efficacy and environmental safety of some essential oils commercial and in vitro extracted pure and combined against four keratinophilic pathogenic fungi. Environmental Health and Preventive Medicine, v. 20, (4), 279 - 286. https:// doi.org/10.1007/s12199-015-0462-6

Itako, A.T.; Schwan-Estrada, K.R.F.; Stangarlin, J.R.; Tolentino Júnior, J.B.; Cruz, M.E.S., 2009. Controle de Cladosporium fulvum em tomateiro por extratos de plantas medicinais. Arquivos do Instituto Biológico, v. 76, (1), $75-83$.

Johann, S.; Silva, D.L.; Martins, C.V.B.; Zani, C.L.; Pizzolatti, M.G.; Resende, M.A., 2008. Inhibitory effect of extracts from Brazilian medicinal plants on the adhesion of Candida albicans to buccal epithelial cells. World Journal of Microbiology and Biotechnology, v. 24, (11), 2459 - 2464. https://doi. org/10.1007/s11274-008-9768-5

Maciel, M.J.; Silva, M.A.S.; Ethur, E.; Avancin, C.A.M., 2017. Indicadores fitoquímicos e atividade antibacteriana do extrato hidroalcoólico bruto de Achyrocline satureioides ("macela") frente Salmonella spp. resistentes a antibióticos isoladas em produtos de origem animal (suínos e aves). Revista Brasileira de Higiene e Sanidade Animal, v. 11, (3), 273 - 287.

Mahboubi, M.; Kazempour, N., 2014. Chemical composition and antimicrobial activity of peppermint (Mentha piperita L.) Essential oil. Songklanakarin Journal of Science and Technology, v. 36, (1), 83 - 87.

Marmitt, D.J.; Rempel, C.; Goettert, M.I.; Silva, A.C., 2015a. As plantas medicinais da Relação Nacional de Plantas Medicinais de Interesse ao Sistema Único de Saúde (RENISUS) com potencial antifúngico. Revista Brasileira de Pesquisa em Saúde, v. 17, (3), 151 - 162.

Marmitt, D.J.; Rempel, C.; Goettert, M.I.; Silva, A.C., 2015b. Plantas com potencial antibacteriano da relação nacional de plantas medicinais de interesse do sistema único de saúde: revisão sistemática. Revista de Saúde Pública, v. 8 , (2), $135-152$.

Martinelli, L.; Rosa, J.M.; Ferreira, C.S.B.; Nascimento, G.M.L.; Freitas, M.S.; Pizato, L.C.; Santos, W.O.; Pires, R.F.; Okura, M.H.; Malpass, G.R.P.; Granato, A.C., 2017. Antimicrobial activity and chemical constituents of essential oils and oleoresins extracted from eight pepper species. Ciência Rural, v. 47, (5), e20160899. https://doi.org/10.1590/0103-8478cr20160899

Mauli, M.M.; Fortes, A.M.T.; Rosa, D.M.; Piccolo, G.; Marques, D.S.; Corsato, J.M.; Leszcynski, R., 2009. Alelopatia de Leucena sobre soja e plantas invasoras. Seminários de Ciências Agrárias, v. 30, (1), 55 - 62.

Moraes, R.C.; Dalla Lana, A.J.; Kaiser, S.; Carvalho, A.R.; Oliveira, L.F.S.; Fuentefria, A.M.; Ortega, G.G., 2015. Antifungal activity of Uncaria tomentosa (Willd.) D.C. against resistant non-albicans Candida isolates. Industrial Crops and Production, v. 69, 7 - 14. https://doi.org/10.1016/j. indcrop.2015.01.033 
Moura-Costa, G.F.; Nocchi, S.R.; Ceole, L.F.; Mello, J.C.P.; Nakamura, C.V.; Dias Filho, B.P.; Temponi, L.G.; Ueda-Nakamura, Y., 2012. Antimicrobial activity of plants used as medicinals on an indigenous reserve in Rio das Cobras, Paraná, Brazil. Journal of Ethnopharmacology, v. 143, (2), 631 - 638. https://doi.org/10.1016/j.jep.2012.07.016

Nogueira, J.C.R.; Diniz, M.F.M.; Lima, E.O., 2008. Atividade antimicrobiana in vitro de produtos vegetais em otite externa aguda. Revista Brasileira de Otorrinolaringologia, v. 74, (1), 118 - 124. https://doi.org/10.1590/S003472992008000100019

Panda, S.K.; Das, R.; Leyssen, P.; Neyts, J.; Luyten, W., 2018. Assessing medicinal plants traditionally used in the Chirang Reserve Forest, Northeast India for antimicrobial activity. Journal of Ethnopharmacology, v. 225, 220 233. https://doi.org/10.1016/j.jep.2018.07.011

Parsaei, P.; Bahmani, M.; Karimi, M.; Naghdi, N., 2016. A review of analgesic medicinal plants in Iran. Scholars Research Library, v. 8, (2), 43 - 51.

Pinho, L.; Souza, P.N.S.; Macedo Sobrinho, E.; Almeida, A.C.; Martins, E.R., 2012. Atividade antimicrobiana de extratos hidroalcoólicos das folhas de alecrimpimenta, aroeira, barbatimão, erva baleeira e do farelo da casca de pequi. Ciência Rural, v. 42, (2), 326 - 331. https://doi.org/10.1590/S0103-84782012005000003

Piriz, M.A.; Lima, C.A.B.; Jardim, V.M.R.; Mesquita, M.K.; Souza, A.D.Z.; Heck, R.M., 2014. Plantas medicinais no processo de cicatrização de feridas: uma revisão de literatura. Revista Brasileira de Plantas Medicinais, v. 16, (3), 628 - 636. https://doi.org/10.1590/1983-084X/12_178

Rajeswara Rao, B.R.; Rajput, D.K., 2010. Global Scenario of Medicinal Plants. In: National Conference on Conservation of Medicinal Plants: Herbal Products and their Uses, 2010. Annals...

REFLORA, 2010. Plantas do Brasil: Resgate histórico e herbário virtual para o conhecimento e conservação da flora brasileira. Instituto de Pesquisa Jardim Botânico do Rio de Janeiro (Accessed July 16, 2020), at: http://floradobrasil. jbrj.gov.br/reflora/PrincipalUC/PrincipalUC.do?lingua=pt.

Rodrigues, E.; Schwan-Estrada, K.R.F.; Fiori-Tutida, A.C.G.; Stangarlin, J.R.; Cruz, M.E.S., 2007. Fungitoxicidade, atividade elicitora de fitoalexinas e proteção de alface em sistema de cultivo orgânico contra Sclerotinia sclerotiorum pelo extrato de gengibre. Summa Phytopathologica, v. 33, (2), 124 - 128. https://doi.org/10.1590/S0100-54052007000200004

Sadat-Hosseini, M.; Farajpour, M.; Boroomand, N.; Solaimani-Sardou, F., 2017. Ethnopharmacological studies of indigenous medicinal plants in the south of Kerman, Iran. Journal of Ethnopharmacology, v. 199, 194 - 204. https://doi. org/10.1016/j.jep.2017.02.006

Santos, A.C.A.; Rossato, M.; Serafini, L.A.; Bueno, M.; Crippa, L.B.; Sartori, V.C.; Dellacasa, E.; Moyna, P., 2010. Efeito fungicida dos óleos essenciais de Schinus molle L. e Schinus terebinthifolia Raddi, Anacardiaceae, do Rio Grande do Sul. Revista Brasileira de Farmacognosia, v. 20, (2), 154 - 159. https://doi.org/10.1590/S0102-695X2010000200003

Saharkhiz, M.J.; Motamedi, M.; Zomorodian, K.; Pakshir, K.; Miri, R.; Hemyari, K., 2012. Chemical Composition, Antifungal and Antibiofilm Activities of the Essential Oil of Mentha piperita L. ISRN Pharm, v. 2012, 718645. https://doi.org/10.5402\%2F2012\%2F718645

Schmourlo, G.; Mendonça-Filho, R.R.; Alviano, C.S.; Costa, S.S., 2005. Screening of antifungal agents using ethanol precipitation and bioautography of medicinal and food plants. Journal of Ethnopharmacology, v. 96, (3), 563 568. https://doi.org/10.1016/j.jep.2004.10.007
Schwan-Estrada, K.R.F.; Stangarlin, J.R.; Silva Cruz, M.E., 2000. Uso de extratos vegetais no controle de fungos fitopatogênicos. Floresta, v. 30, (1-2), 129 - 137. https://doi.org/10.5380/rf.v30i12.2361

Silva, N.C.C., 2010. Estudo comparativo da ação antimicrobiana de extratos e óleos essenciais de plantas medicinais e sinergismo com drogas antimicrobianas. Dissertation, Instituto de Biociências, Universidade Estadual Paulista "Júlio de Mesquita Filho", São Paulo (Accessed March 2, 2020), at: https://repositorio.unesp.br/bitstream/handle/11449/87809/silva_ncc_me_ botib.pdf?sequence $=1$ \&isAllowed $=\mathrm{y}$.

Simões, C.M.O.; Schenkel, E.P;; Mello, J.C.P.; Mentz, L.A.; Petrovick, P.R., 2017. Farmacognosia: do produto natural ao medicamento. Artmed, Porto Alegre.

Sixel, P.J.; Pecinalli, N.R., 2005. Características farmacológicas gerais das plantas medicinais. Infarma, v. 16, (13-14), 74 - 77.

Souza Júnior, U.P.; Pereira. J.V.; Pereira, M.S.V.; Costa, M.R.M.; Pereira, A.V.; Antunes, R.M.P., 2011. Atividade antifúngica in vitro do extrato da Uncaria tomentosa l. (unha de gato) sobre cepas do gênero Candida. Pesquisa Brasileira de Odontopediatria e Clínica Integrada, v. 11, (4), 477 - 480. https:// doi.org/10.4034/PBOCI.2011.114.03

Tamariz-Angeles, C.; Oliveira-Gonzales, P.; Santillán-Torres, M., 2018. Antimicrobial, antioxidant and phytochemical assessment of wild medicinal plants from Cordillera Blanca (Ancash, Peru). Blacpma, v. 17, (3), 270 - 285.

Tandon, N.; Yadav, S.S., 2017. Contributions of Indian Council of Medical Research (ICMR) in the area of Medicinal plants/Traditional medicine. Journal of Ethnopharmacology, v. 197, 39 - 45. https://doi.org/10.1016/j. jep.2016.07.064

Taxonomic Name Resolution Service. iPlant Collaborative. Version 4.0 (Accessed July 16, 2020), at: http://tnrs.iplantcollaborative.org.

Tyagi, A.K.; Malik, A., 2011. Antimicrobial potential and chemical composition of Mentha piperita oil in liquid and vapour phase against food spoiling microorganisms. Food Control, v. 22, (11), 1707 - 1714. https://doi. org/10.1016/j.foodcont.2011.04.002

Vamanu, E.; Vamanu, A.; Nita, S.; Colceriu, S., 2011. Antioxidant and Antimicrobial Activities of Ethanol Extracts of Cynara Scolymus (Cynarae folium, Asteraceae Family). Tropical Journal of Pharmaceutical Research, v. 10, (6), 777 - 783. https://doi.org/10.4314/tjpr.v10i6.11

Van Wyk, B.E.; Wink, M., 2018. Medicinal plants of the world. CABI, Boston.

Vasconcelos Silva, M.G.; Craveiro, A.A.; Matos, F.J.A.; Machado, M.I.L.; Alencar, J.W., 1999. Chemical variation during daytime of constituents of the essential oil of Ocimum gratissimum leaves. Fitoterapia, v. 70, (1), 32 - 34.

Vizzotto, M.; Krolow, A.C.R.; Weber, G.E.B., 2010. Metabólitos secundários encontrados em plantas e sua importância. Embrapa Clima TemperadoDocumentos (INFOTECA-E) (Accessed March 6, 2020), at: https://www. infoteca.cnptia.embrapa.br/bitstream/doc/886074/1/documento316.pdf.

Zeni, A.L.B.; Parisotto, A.V.; Mattos, G.; Helena, E.T.S., 2017. Utilização de plantas medicinais como remédio caseiro na Atenção Primária em Blumenau, Santa Catarina, Brasil. Ciência e Saúde Coletiva, v. 22, (8), 2703 - 2712. https:// doi.org/10.1590/1413-81232017228.18892015

Zhu, X.; Zhang, H.; Lo, R., 2004. Phenolic Compounds from the Leaf Extract of Artichoke (Cynara scolymus L.) and Their Antimicrobial Activities. Journal of Agricultural and Food Chemistry, v. 54, (24), 7272 - 7278. https://doi. org/10.1021/jf0490192 